\title{
IKLAN PROVIDER SELULER XL DENGAN STRATEGI PEMASARAN BERBASIS LOKAL MADURA (SEBUAH KAJIAN DESAIN)
}

\author{
Naufan Noordyanto \\ Program Pascasarjana Institut Seni Indonesia Yogyakarta \\ noordbita@gmail.com
}

\begin{abstract}
Abstrak
Dalam salah satu strategi promosinya, XL menggunakan iklan yang memunculkan pesan utama dalam slogan berbahasa Madura sebagai upaya pendekatan komunikasi untuk menjangkau konsumen lokal di kawasan Madura, Jawa Timur. Iklan tersebut bertuliskan "ORENG MADHURE KABBHI NGANGGUY XL" (secara literal artinya “orang Madura semua menggunakan XL”). Materi iklan tersebut menunjukkan klaim XL yang diasumsikan mengandung unsur kontroversial bahwa semua orang Madura menjadi konsumen produk XL tanpa menyajikan bukti data statistik. Mengingat iklan ini cenderung didominasi oleh pesan verbal, maka kajian ini bermaksud melengkapi celah teoritis terkait upaya analisis iklan dengan menginterpretasikan makna tersembunyi yang terkandung dalam materi iklan secara kritis dan lepas dari maksud pengiklan. Analisis dilakukan melalui pendekatan interpretasi Paul Ricoeur yang dihubungkan dengan konteks sosial budaya, dan dukungan teori tipografi. Kajian ini juga berupaya melengkapi pengetahuan tentang upaya promosi produk di kalangan lokal dari produsen skala nasional dan praktik promosi produk yang dilakukan dalam konteks sosial budaya. Melalui kajian ini, ditemukan bahwa pernyataan "kabbhi" atau "semua" dalam slogan tidak mengacu pada kondisi realitas. Pola konsumsi yang ditawarkan tersebut mendikte konsumen dengan iming-iming fungsi kolektif melalui materi identitas dan simbolik kebudayaan Madura. Seolah-olah produk XL menjadi pilihan pakai yang diinginkan masyarakat lokal dan menawarkan kebanggaan kolektif komunal. Selain itu, iklan tersebut diasumsikan seperti ingin menunjukkan dukungan terhadap ketidakberesan sosial yang memunculkan kesan bahwa korporasi tidak pernah peduli dengan edukasi dan perbaikan tingkat intelektualitas masyarakat lokal. Bahkan penulisan ejaan teks iklan yang kurang tepat, terkesan sembarang justru mengkonotasikan bahwa korporasi yang bersangkutan tak pernah ambil peduli pada edukasi dan perawatan tradisi kebudayaan lokal, khususnya dalam konteks kebahasaan.
\end{abstract}

Kata kunci: iklan, XL, seluler, madura, budaya

\begin{abstract}
In one of their promotional strategy, XL use ads that present the main message of slogan that used Madura language as a communication approach to reach the local customer in Madura Island, East Java. The ads reads "ORENG MADHURE KABBHI NGANGGUY XL" (which means "the all Madurese use XL"). The message indicates the XL claim that assumed of the controversial contain that all Madurese is the customers of their products without presenting the evidences of statistical data. In because of the ads is dominated by the verbal message elements, so this
\end{abstract}


study intend to cover the theoretical gap about ads analysis methods by interpreting the hidden meaning contained in advertising elements, critically and free from the advertiser purpose and concern. The analysis is conducted through the approach of Paul Ricoeur interpretation theory associated with socio-cultural contexts, and also supported by the theory of typography. The study also intend to contribute the knowledge for the science of design about the products promotional strategy in local customers area that is done by national scale manufactures, and the products promotion practices undertaken in the socio-cultural context. Through this study, it can be revealed that the statement "kabbhi" or "all" in the slogan does not refer to the condition of reality. The consumption patterns that offered, dictating the consumers with the lure of collective functions and values through the material and symbolic cultural identity of Madura. As if the XL products become a choice to use that is desired by local communities and offer a communal collective pride. In addition, the ads are assumed to show the support the social irregularities which impress that the corporation was never concerned with education and the improvement of intellectual level of local communities. Even the spelling of text ads that are less true, impress that the corporation never take care about the education and care of local cultural traditions, especially in the context of local language.

Keywords: ads, XL, cellular, madura, culture

\section{Pendahuluan}

Kontestansi pasar antar provider seluler di Indonesia untuk meraih hati konsumen, dilakukan dengan ragam strategi pendekatan, salah satunya melalui pendekatan budaya lokal. Hal ini misalnya dijumpai pada iklan provider seluler XL di kawasan Madura, yang memunculkan unsur iklan berbahasa Madura sebagai bentuk upaya pendekatan komunikasi terhadap konsumen masyarakat Madura. Ragam promosi ini berupa iklan luar ruang pada medium muka dinding bangunan pinggir jalan, posterposter, label kursi, hingga pada desain kemasan label kartu SIM (Subscriber Identity Module). Dalam hal ini data visual yang berhasil ditemukan adalah iklan dari provider XL yang dikeluarkan oleh PT XL Axiata Tbk yang disebar di wilayah Madura. Pola iklan dari provider ini dipilih sebagai obyek material kajian karena dalam pesannya menunjukkan klaim yang diasumsikan mengandung unsur kontroversial bahwa orang Madura (semua) menjadi konsumen produk mereka.

Citra budaya Madura melalui penggunaan unsur-unsur materi teks yang secara global menjadi kebudayaan nasional, misalnya seperti bubuhan pesan verbal berbahasa Madura yang maknanya hanya dimengerti oleh kebanyakan masyarakat Madura. Artinya ada upaya khusus dari provider sebagai pengiklan untuk melakukan strategi pendekatan dalam promosi produk layanannya di Madura. Sebab bisa saja provider memakai materi promosi global (nasional) yang seragam dengan corak visual ke-Indonesiaan dan berbahasa Indonesia secara universal. Namun, justru fakta empirisnya dijumpai bahwa pihak provider menyiapkan secara khusus untuk promosi berbasis lokal lokal, khususnya dalam hal ini kawasan Madura.

Selain itu, kontestansi antar provider seluler yang ditunjukkan dengan klaim terbaik bagi orang Madura dan menyatakan Orang Madura (semua) menjadi 
konsumennya tanpa menyajikan bukti data statistik mengidentifikasikan bahwa unsur iklan merupakan tanda yang diolah dalam rangka kepentingan meraih pasar. Unsur iklan dalam modus pendekatan kebudayaan lokal menjadi tanda yang ditata sedemikian rupa untuk mengarahkan konsumsi akan unsur visual, informasi, dan janji yang ditawarkan. Produk yang diiklankan menjadi menarik karena seolah-olah menjadi pilihan pakai yang diinginkan masyarakat lokal dan menawarkan kebanggaan klaim yang banyak dipakai masyarakat lokal Madura. Padahal sebagaimana disebutkan di atas, produk-produk layanan seluler yang dipasarkan berbasis lokal tersebut sejatinya dipasarkan dalam diaspora pasar global.

Beranjak dari permasalahan di atas, kajian ini bermaksud menginterpretasikan makna dibalik penggunaan materi iklan dengan pendekatan budaya lokal Madura tersebut. Mengingat menurut MacRury (2009: 4) bahwa iklan tidak hanya sebagai instrumen pemasaran, tetapi juga sebagai lembaga sosial budaya yang membujuk, mendidik, dan mensosialisasikan masyarakat konsumen dengan mengedarkan nilai-nilai dan kegunaan, makna-makna, dari barang dan jasa sehingga dapat terjual/laku di pasaran. Dalam rangka mengungkap makna dibalik materi iklan tersebut, kajian ini dilakukan melalui metode berbeda dengan kajian umumnya yang menggali makna dan maksud iklan dari sisi pengiklan. Kajian ini justru bersifat otonom, yaitu melepaskan iklan dari horizon pengiklan dalam mengungkap makna dibalik materi iklan tersebut. Sebagai sumbangsih terhadap ilmu pengetahuan Desain Komunikasi Visual (DKV), kajian ini berupaya melengkapi celah teoritis terkait upaya analisis iklan yang dipandang lepas dari maksud pengiklan dengan menginterpretasikan makna tersembunyi yang terkandung dalam materi iklan. Mengingat iklan ini cenderung didominasi oleh pesan verbal dan mengandung klaim sepihak dari XL tersebut, maka analisis untuk mengungkap makna tersembunyi pada iklan lebih dilakukan dengan teori interpretasi makna secara kritis yang dihubungkan dengan konteks sosial budaya, dan dukungan teori tipografi. Sehingga analisis dilakukan melalui upaya memberi jarak antara iklan dengan pengiklan, dan menginterpretasikan makna tersembunyi secara kontekstual dan menawarkan gagasan kritis atas materi pendekatan iklan provider XL yang penulis jumpai. Kajian ini juga berupaya melengkapi pengetahuan tentang upaya promosi produk di kalangan lokal, khususnya di Madura, dari produsen skala nasional. Sekaligus juga melihat praktik promosi produk yang dilakukan dalam konteks sosial budaya.

Adapun rumusan masalah dari kajian ini adalah "bagaimana interpretasi makna secara kritis dibalik materi iklan XL berbahasa Madura versi Oreng Madhure Kabbhi Ngangguy Xl”. Hal ini dapat meliputi representasi, organisasi tanda dan teks iklan, dan pihak yang ditutupi, dalam pola materi iklan provider seluler XL yang diangkat dalam kajian ini.

Kajian ini dibatasi pada obyek material berupa iklan XL dengan materi desain pendekatan budaya Madura melalui penggunaan ikon budaya Madura (bahasa Madura). Iklan ini dibatasi penelitiannya pada temuan di wilayah geografis Madura. 


\section{Metode Penelitian}

Metode pengumpulan data dilakukan dengan observasi langsung di lokasi penelitian untuk mendapatkan data visual. Selain itu, pengumpulan data dan landasan teori juga dilakukan dengan kajian pustaka. Kajian ini dilakukan dengan analisis kualitatif, yaitu menganalisis unsur iklan untuk menginterpretasikan makna-makna tersembunyi dengan menawarkan gagasan kritis atas materi pendekatan iklan provider XL yang penulis jumpai. Analisis lebih difokuskan pada materi promosi yang berunsur pendekatan budaya Madura, yaitu iklan XL berwujud dua dimensi (2D) versi "ORENG MADHURE KABBHI NGANGGUY XL”. Mengingat iklan ini cenderung didominasi oleh pesan verbal, maka teks iklan dan unsur visual diberlakukan sebagai teks yang dapat dibaca dan diinterpretasikan. Analisis untuk mengungkap makna tersembunyi pada iklan lebih dilakukan dengan teori interpretasi secara kritis yang dihubungkan dengan konteks sosial budaya, dan dukungan teori tipografi. Analisis bersifat multiparadigma, dan merawat keterbukaan atas upaya interpretasi lain. Analisis interpretatif dalam kajian ini bersifat otonom, lepas dari horizon pengiklan. Artinya interpretasi dilakukan tanpa harus melihat dan mengungkap makna dan maksud dari sisi pengiklan. Oleh karena itu, metode interpretasi dalam kajian ini dilakukan dengan meminjam instrumen interpretasi berupa konsep “distansiasi” dan “apropriasi” dari Paul Ricoeur.

Mengingat dalam kajian iklan ini terjadi problem “distansiasi”, yaitu "pen-jarakan” (jarak kejadian spasial atau jarak temporal) yang terjadi karena adanya kesenjangan antara dunia iklan yang “dibaca” oleh interpretator selaku peneliti dengan dunia pengiklan. Sehingga juga muncul “apropriasi” yaitu “menjadikan apa yang asing menjadi milik interpretator” (Ricoeur, 2012: 95). Sesuatu yang asing maksudnya adalah upaya interpretasi mandiri yang dilakukan peneliti. Sehingga penulis dapat mengambil jarak (distansiasi) dari sisi obyektif iklan yang dimaksud pengiklan, tetapi juga memungkinkan untuk melakukan apropriasi atau penelusuran makna (kontekstual) secara mandiri (subyektif) dan kreatif melalui interpretasi atas kondisi sosial dan budaya yang melingkupinya (Ricoeur, 2012: 95 dan Fashri, 2014: 36-38).

\section{Iklan dan Strategi Promosi Provider XL di Madura}

Iklan yang diurai dalam konteks kajian ini dipahami sebagai bentuk promosi komersial. Artinya makna iklan cakupannya lebih luas sebagai metode atau medium pemasaran produk. Sebagaimana disebut MacRury (2009: 4) bahwa iklan sebagai instrumen, alat ekonomi, yang digunakan dalam pemasaran ("as an instrument, an economic tool, used in marketing”). Iklan menjadi cara atau justru sebagai media penyampai pesan untuk kepentingan komersial dan kepentingan benefit korporasi. Materi komunikasi yang dominan digunakan dalam iklan meliputi unsur visual dan teks (сору) (MacRury, 2009: 5). Dalam hal ini, materi iklan milik provider seluler dengan strategi promosi pendekatan budaya Madura yang penulis jumpai, kecenderungannya menggunakan unsur visual dan teks. Beberapa materi iklan yang dikaji yaitu milik perusahaan/provider layanan seluler yang mengeluarkan produk XL. Iklan XL 
dikeluarkan oleh PT XL Axiata Tbk. PT XL Axiata Tbk (selanjutnya disebut provider XL) merupakan salah satu di antara penyedia layanan seluler terkemuka di Indonesia. Perlu diketahui, bahwa strategi promosi juga tak lepas dari karakteristik konsumen dan kondisi pasar di Madura. Jumlah penduduk Madura mencapai 3,62 juta jiwa pada dasarnya dalam hitungan kotor (bruto) merupakan pasar yang gemuk untuk ekspansi bisnis. Sebagaimana diketahui, SP 2010 yang dilakukan oleh Badan Pusat Statistik (BPS) (Diakses pada 9 Juni 2016, pukul 13.41 WIB), angka jumlah penduduk Madura di atas memiliki komposisi: kabupaten Bangkalan 906.761 jiwa, Sampang 877.772 jiwa, Pamekasan 795.918 jiwa, Sumenep 1.042.312 jiwa. Oleh karena potensi pasar Madura ini, penulis melihat provider ramai-ramai berupaya menjangkau dan mengikat loyalitas masyarakat Madura selain dengan program layanan seluler dan tarif khusus untuk masyarakat Madura, juga dengan strategi promosi pendekatan sosial dan kebudayaan setempat sebagaimana disinggung sebelumnya.

Ditulis dalam laman resminya (XL Axiata, diakses pada 9 Juni 2016, pukul 10.39 WIB), sejak meluaskan bisnisnya di sektor komunikasi pada 1996, XL merupakan perusahaan swasta pertama di Indonesia yang menyediakan layanan telepon seluler. XL mengklaim bahwa jaringannya memadai di seluruh pulau Madura dan pada Desember 2015 tercatat memiliki jumlah pengguna terbanyak di Madura, yaitu sekitar 1,37 juta konsumen (Xl Axiata, 28 Desember 2015, diakses pada 9 Juni 2016, pukul 10.38 WIB). Artinya jumlah konsumen XL pada 2015 mencapai sekitar 37, 8\% jumlah penduduk Madura berdasarkan Sensus Penduduk 2010 (SP 2010).

Bahkan berdasarkan berita yang dirilis laman berita asal Surabaya, kabarbisnis.com pada 14 Mei 2009 (diakses pada 9 Juni 2016, pukul 11.05 WIB), meninjau pada 2009 lalu pun, XL menjadi market leader di Madura, dan berkontribusi lebih dari 50\% konsumen dan pendapatan XL wilayah timur. Begitu pula dalam berita kabarbisnis.com pada 6 Juni 2014 lalu (diakses pada 9 Juni 2016, pukul 12.50 WIB), 90\% area di 4 (empat) kabupaten di Madura terjangkau layanan XL, dan XL mengklaim menguasai pasar Madura dengan market share sekitar 85\%.

Berbeda dengan provider lain, misalnya jumlah konsumen telkomsel di wilayah Madura berdasarkan berita yang dirilis Sindonews.com pada 6 Mei 2015 (diakses pada 11 Juni 2016, pukul 10.51 WIB), mencapai 525.000 konsumen layanan Telkomsel dasar atau sekitar 14,5\% jumlah penduduk Madura, dan mencapai 340.000 konsumen layanan data atau 9,3\% jumlah penduduk Madura berdasarkan perhitungan dari SP 2010. Selain itu, berdasarkan kabarbisnis.com pada 24 Juni 2013 (diakses pada 11 Juni 2016, pukul 13.54 WIB), jumlah konsumen Indosat di Madura pada 2013 mencapai 250 ribu konsumen dengan market share sekitar 20 persen dari total pengguna seluler di Madura. Oleh karena itu, jika melihat kekuatan posisi pasar XL di Madura, upaya strategi promosi lokal, bisa jadi merupakan upaya pendekatan untuk mengikat dan menaikkan loyalitas konsumen lokal secara emosional. Dengan instrumen pendekatan kebudayaan, membuat XL seolaholah memiliki citarasa lokal, menjadi kebanggaan lokal, dan menjadi dekat dengan perawat kebudayaan lokal. 


\section{Identifikasi dan Analisis Iklan XL}
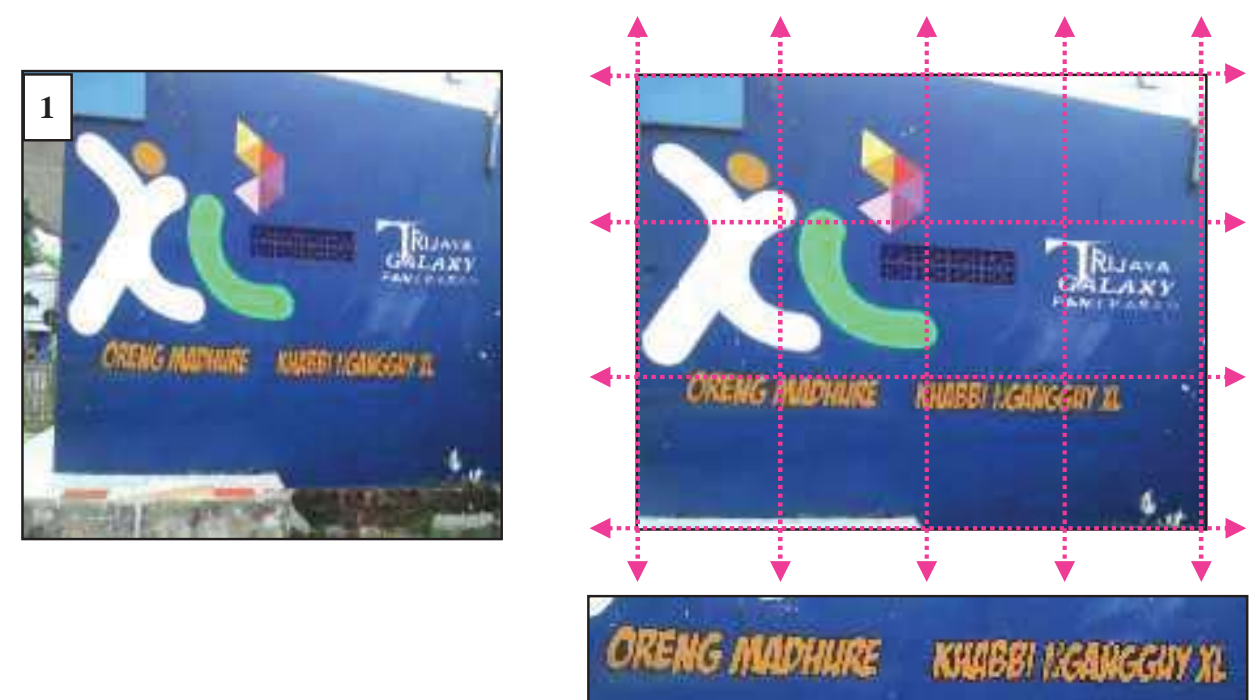

Gambar 1. Bedah layout iklan XL pada muka dinding studio foto milik warga yang berlokasi di sekitar simpang tiga jalan Sedangdang dan jalan Kesehatan Pamekasan

Foto: Kontribusi Athi’ Nur Auliati Rahmah, Juni 2016

Iklan XL dengan materi promosi budaya Madura yang penulis jumpai di wilayah Madura cukup beragam. Ragam iklan yang dipakai di antaranya seperti pada muka dinding bangunan di pinggir jalan, dan kursi plastik untuk konsumen counter atau kedai selular. Adapun iklan luar ruang XL yang dijumpai sebagai sampel yaitu pada muka dinding studio foto milik warga yang berlokasi di sekitar simpang tiga jalan Sedangdang dan Jalan Kesehatan Pamekasan, teridentifikasi memiliki dimensi bidang gambar sekitar 3 x 2 meter.

Organisasi keseluruhan unsur desain meliputi unsur visual dan teks. Tata letak unsur visual dan teks didesain tidak simetris di atas latar belakang warna korporat (corporate color) biru XL. Unsur visual berupa logo XL lama (2009-2014) ditata sangat dekat dengan batas sisi sebelah kiri sebagai ilustrasi utama dan menghabiskan ruang sekitar empat per dua belas bagian sisi bangunan sehingga beban komposisi rupa ada di sisi kiri.

Di bawahnya, terdapat satu baris slogan bertuliskan "ORENG MADHURE KABBHI NGANGGUY XL" yang didesain dengan outline hitam dan fill in jingga, serta dikemas dalam format huruf kapital. Secara keseluruhan, teks slogan berjenis huruf sans serif (tanpa kait) dan cenderung masuk dalam kategori gaya huruf miscellaneous (ragam bebas). Teks slogan ini berada di bagian sepertiga sisi tinggi dinding. Selain itu juga terdapat identitas visual endorsement atau pendukung iklan dengan warna putih, yaitu bertuliskan Trijaya Galaxy Pamekasan, di bagian kanan. Identitas endorsement tersebut mengidentikasikan distributor XL bernama Trijaya Galaxy dengan kantor yang berlokasi agak jauh dari gedung tersebut, namun sama-sama di area kota Pamekasan.

Iklan ini memungkinkan dapat dibaca sesuai alur mata dari kiri ke kanan. Dari seberang jalan sesuai arus lalu lintas, tampak logo XL yang berukuran relatif besar, warna 
terang, dan paling dekat dengan pinggir jalan raya menjadi pusat perhatian, sehingga cenderung mudah terlihat dan terbaca pertama kali. Latar belakang warna biru membuat logo XL dan teks slogan menjadi tampak kontras dan memudahkan untuk terlihat jelas. Selain karena area gambar terhambat adanya lubang ventilasi, posisi ilustrasi utama berupa logo XL yang sangat mendekati batas sisi sebelah kiri seperti ada upaya dari pengiklan agar unsur visual tersebut dekat menjorok dengan jalan raya. Sehingga logo yang pada huruf pertama berwarna putih, menjadi sangat kontras dan menonjol sebagai pusat perhatian awal. Artinya, logo XL tersebut pertama-tama diusahakan sesegera mungkin mendapat perhatian masyarakat sekitar dengan berusaha mengekploitasi ruang pandang masyarakat di sekitar lokasi tersebut. Harapannya kemudian ialah memungkinkan pengguna jalan dapat terus membaca hingga pesan teks selanjutnya.
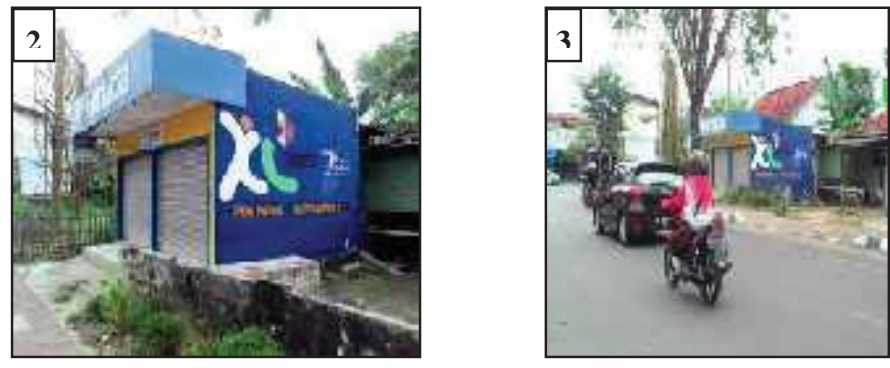

Gambar 2-3. Iklan XL pada muka dinding studio foto milik warga yang berlokasi di sekitar simpang tiga jalan Sedangdang dan jalan Kesehatan Pamekasan

Dari komposisi iklannya yang menonjolkan unsur visual yang relatif besar dan kontras, serta dengan teks singkat, mengidentifikasikan ruang pandang yang menjadi pusat perhatian untuk “dieksploitasi” adalah milik pengguna jalan yang mobile/bergerak melintas, serta memiliki kesempatan melihat dan memperhatikan sekitar dengan singkat. Dari kriteria tersebut pula, terlebih memperhatikan iklan yang didesain tanpa ilustrasi lain yang dibuat khusus, dapat diduga bahwa iklan ini memiliki fungsi pengingat (reminding) masyarakat pada merek XL. Apalagi juga didukung dengan pesan iklan disampaikan dengan slogan utama berbahasa Madura dengan ide yang spesifik, yaitu bertuliskan “ORENG MADHURE KHABBI NGANGGUY XL”, (baca: oreng Madhureh kabbhi ngangghuy $X L$, artinya “Orang Madura semua menggunakan/memakai XL”). Melalui iklan ini, XL seolah-olah lebih ingin menunjukkan kestabilan posisi pemasarannya di Madura yang menjadi market leader, sebagaimana disajikan data pada uraian di atas.

Iklan yang serupa dengan visualisasi iklan di atas salah satunya juga dijumpai pada atribut dan medium promosi yang lain, di antaranya pada medium label sisi samping kursi plastik di kedai seluler Lira Cell sekitar simpang empat jalan Kemayoran dan jalan Kolpajung Pamekasan. Melihat fenomena ini, ternyata iklan ini sekaligus bertransformasi menjadi identitas visual yang dwifungsi. Baik sebagai identitas XL atau iklan itu sendiri, meskipun keduanya sama-sama merupakan instrumen pemasaran. Mengingat ilustrasinya hanya menonjolkan warna biru kursi, logo XL, dan teks yang bisa disebut slogan untuk promosi lokal. 
Upaya yang dilakukan pihak XL bisa dibilang sebagai strategi hemat agar mudah diingat, dengan menonjolkan dan mementingkan keseragaman identitas dalam promosi melalui tampilan logo dan slogan berbahasa Madura tersebut pada beragam media. Bedanya hanya pada komposisi, dimensi, teknik visualisasi. Jika iklan XL pada dinding bangunan dibuat dengan menggambar manual dan relatif besar dengan komposisi asimetris, iklan pada kursi dibuat dalam komposisi simetris (seimbang tengah) dengan teknik komputerisasi dalam bentuk sticker tempel sesuai dimensi space iklan pada kursi. Hal ini tentu saja berakibat pada penetrasi informasi yang disampaikan menghendaki target audiens untuk melihat dari jarak yang relatif lebih dekat, terutama bagi calon konsumen yang datang di kedai seluler tersebut. Dengan karakter yang serupa dengan iklan ruang di atas, dapat diduga pula bahwa iklan ini memiliki fungsi pengingat (reminding) terhadap merek XL sebagaimana diurai sebelumnya.
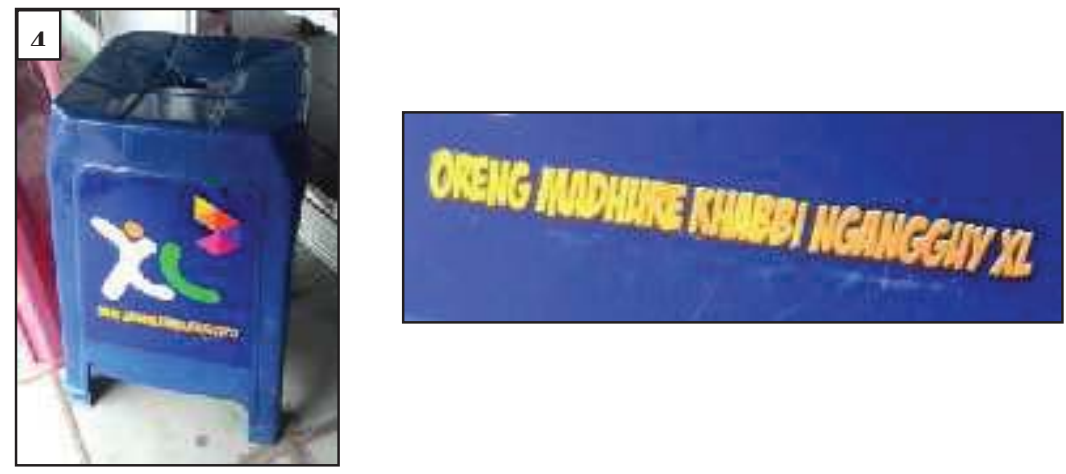

Gambar 4. Iklan XL pada muka sisi kursi untuk konsumen di kedai seluler Lira Cell sekitar simpang empat jalan Kemayoran dan jalan Kolpajung Pamekasan

Foto: Kontribusi Athi’ Nur Auliati Rahmah, Juni 2016

Namun, berkaitan penggunaan logo XL lama pada iklan tersebut yang masih dijumpai hingga sekarang, bisa jadi karena iklan tersebut telah relatif lama disepakati dan dibuat pada sekitar rentang tahun logo tersebut dipakai (2009 -2014, berdasarkan laman resmi XL Axiata). Apalagi jika menyimak pesan yang ingin mengatakan bahwa Orang Madura (semua) menggunakan XL. Mengingat pada tahun tersebut juga berdasarkan data yang disajikan sebelumnya, XL sudah memimpin pasar di Madura. Hanya secara fisik, tampilan cat saja yang diperbaharui agar tampak selalu mulus dan tidak usang, meskipun XL telah merilis logo barunya pada Oktober 2014 (laman resmi XL Axiata).

\section{Tipografi}

Terlepas dari tata bahasa, pemilihan diksi, dan semantiknya, visualitas huruf tersebut dapat dipandang dalam fokus perhatian tipografi. Dalam Klimchuk dan Krasovec (2012: 65), secara etimologi, istilah tipografi sendiri berasal dari bahasa Yunani, yaitu “typo" berarti impresi (impression), dan "graphein” berarti menulis (to write). Tipografi menekankan penggunaan rupa/bentuk huruf untuk mengkomunikasikan secara visual suatu bahasa verbal. 
Visualitas bahasa dalam pesan tersebut disajikan dengan rupa huruf (typeface) berkarakter miscellaneous dengan karakternya yang bebas/dekoratif. Dalam hal anatomi huruf, struktur garis (stroke) horizontal masing-masing huruf kecenderungannya memiliki kemiringan ke arah kanan atas, serta memiliki contrast atau tebal-tipis huruf yang cenderung organik dan dinamis. Hal tersebut membentuk arah gerak imajiner cenderung naik turun, dan mengesankan transformasi imajinatif dan visualisasi kreatif dari tone dan tekanan (intonasi) dalam dialog/tutur manusia atau efek bunyi tertentu. Di samping itu, rupa huruf (yang dapat dilihat di gambar) tersebut, mengingatkan pada rupa huruf digital bernama "Badaboom BB", atau huruf berkarakter serupa lainnya, yang sering dipakai dalam komik. Badaboom BB merupakan huruf digital (font) yang diproduksi dan dirilis oleh laman penyedia font komputer Blambot Comic Font \& Lettering (Blambot.com) asal Rhode Island, Amerika Serikat, yang mengklaim sering membuat font untuk industri komik seperti Marvel dan DC Comic. Sementara itu, di laman penyedia unduhan font gratis seperti dafont.com, rupa huruf Badaboom BB dimasukkan dalam kategori "Fancy". Hal ini barangkali ingin menunjukkan huruf tersebut merupakan adaptasi imajinatif/khayal atas transformasi dan visualisasi kreatif dari tone dan tekanan (intonasi) dalam dialog/tutur manusia atau efek bunyi tertentu sebagaimana yang diurai sebelumnya.

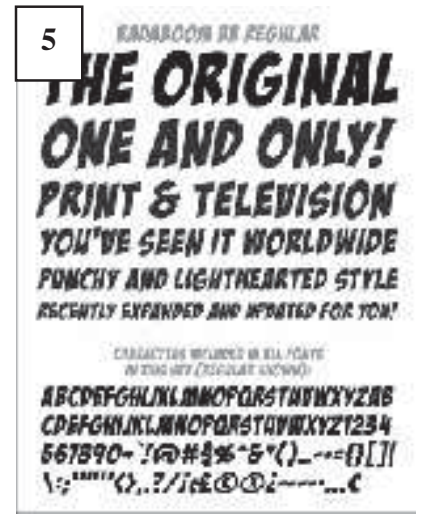

Gambar 5. Preview rupa huruf Badaboom BB yang dikeluarkan oleh Blambot.com Sumber: Blambot.com, Badaboom BB. Diakses pada 11 Juni 2016, pukul 10.56 WIB

Rupa huruf tersebut sering dipakai dalam komik untuk menguatkan kesan ekspresi dalam dialog, terutama efek bunyi ledakan (BADA-BOOM!), pukulan, dan lainlain. Namun tentu saja, dalam iklan ini, kemungkinan untuk merepresentasikan efek bunyi ledakan, pukulan, dan lain-lain, sangat lemah. Terlebih rupa masing-masing huruf pada slogan iklan XL tersebut diatur dengan dimensi yang seragam, rata dalam satu baris, tidak ada penekanan yang lebih besar atau kecil untuk menguatkan ekspresi. Bisa diduga, selain untuk mendapat kesan artistik semata, desain huruf seperti ini bisa merepresentasikan eskpresi visual tutur pesan verbal yang ingin disampaikan pengiklan.

Dari hasil analisis rupa/bentuk huruf melalui stroke dan contrast huruf, jenis huruf, kecenderungan penggunaan huruf sebagaimana diulas di atas, ekspresi visual huruf dari teks verbal slogan merefleksikan tone yang eskpresif, ramah, fancy, dan fun. 
Sebagaimana diketahui dalam tipografi, bahwa rupa huruf sering diidentikkan dengan penampilan yang diasosiasikan dengan konteks tertentu. Dari mengamati rupa atau penampilan huruf dapat dirangkum atau ditangkap tentang karakteristik, kesan, atau nuansa yang dimunculkannya. Sebagaimana menurut Sihombing (2001: 66), interpretasi yang ditangkap tersebut merupakan "asosiasi terhadap realita yang didapat berbagai macam referensi dan rekaman berbagai pengalaman”. Dengan konsep ini pula, dapat dilihat bahwa karakter desain huruf tersebut menguatkan legitimasi maksud penyampaian pesan dengan gaya komunikasi yang ekspresif bahwa orang Madura menggunakan XL. Dapat diduga, karakter desain huruf yang demikian sebagai strategi untuk meniru, mengadaptasi, dan menyesuaikan karakteristik audiens masyarakat Madura yang identik dengan stereotip gaya tutur yang ekspresif, ngomik, dan ramah/hangat. Dengan kata lain, pesan utama dalam slogan tersebut ingin dituturkan dengan gaya komunikasi masyarakat Madura melalui representasi bahasa visual dari teks verbal tersebut.

Selain itu, rupa hurufnya yang sengaja dibuat tidak eksklusif (dengan karakter kaku, klasik, elegan), tetapi dibuat lebih fancy, fun, ekspresif, mengindikasikan sasaran iklan memang bermaksud tidak mengkhususkan pada kelas sosial tertentu, apalagi kelas atas (eksklusif), tetapi ingin menjangkau pasar masyarakat Madura secara luas. Sehingga maunya XL dapat menjadi pilihan produk yang pasaran selaras dengan pesan slogan berbahasa Madura tersebut.

Penggunaan warna jingga untuk fill in pada huruf-huruf yang menyusun slogan mendukung kontras warna huruf dengan latar belakang yang biru, apalagi dikelilingi dengan outline hitam. Warna jingga merupakan warna hangat di antara warna merah dan kuning dalam jajaran warna. Warna jingga salah satunya dapat dijumpai pada warna matahari (senja), dan diasosiasikan dengan energi dan gairah. Dalam hal ini, energi dan gairah bisa disejajarkan dan disandingkan dengan nuansa ekspresif sebagaimana galian makna interpretatif dari karakter bentuk/rupa huruf, yaitu bertransformasi menjadi kata sifat enerjik. Sehingga mendukung kesan dan nuansa bergairah, enerjik, kehangatan/keramahan dalam penyampaian maksud pesan seperti diulas sebelumnya. Sementara warna outline hitam pada huruf, penulis pahami hanya sebagai penguat aksentuasi saja. Hal ini karena karakter outline tersebut relatif tipis, tetapi fungsinya dapat menguatkan kontras warna fill in terhadap latar belakang dengan menciptakan area gelap di sekitar warna fill in pada tubuh huruf. Dari sini diketahui bahwa penyampaian pesan melalui visualisasi bahasa melalui rupa/bentuk dan warna huruf diusahakan pengiklan agar selaras dengan pesan yang ingin disampaikan.

\section{Organisasi Keseluruhan Teks}

Hal menarik dalam pendekatan dengan unsur budaya Madura pada iklan ini yaitu penggunaan teks berbahasa Madura untuk menyampaikan pesan. Teks ini diekspresikan dalam wujud slogan yang disusun dalam empat kata, yaitu "ORENG MADHURE KHABBI NGANGGUY XL". Dalam bahasa Indonesia makna slogan tersebut secara literal yaitu "Orang Madura semua menggunakan/memakai XL”.

Pesan tentang XL banyak digunakan orang Madura disajikan ringkas dalam satu baris teks tersebut. Susunan kalimat dalam slogan bentuknya transitif, yaitu memiliki kata 
kerja yang membutuhkan/ada obyek. Narasi diringkas dalam satu kata kerja aktif "NGANGGUY" - atau "memakai/menggunakan", atau lebih lengkapnya "NGANGGUY $X L$ ” atau "memakai/menggunakan XL”. Penggunakan kata kerja aktif dengan obyeknya ini ingin mengacu pada aktivitas apa dan siapa yang beraktivitas. Atau lebih khususnya “siapa yang memakai/menggunakan XL?”. Namun, ternyata penyebutan “siapa” tidak cukup dengan mencantumkan subyek noun secara mandiri, tetapi diikuti dengan kata keterangan (adverbia) untuk memberi karakteristik pada "siapa”. Yaitu "ORENG" atau "orang. Tetapi didukung dengan kata keterangan etnis atau tempat - MADHURE" atau "Madura”- yang dimaksudkan pada "ORENG MADHURE” atau "orang Madura”, serta juga keterangan numeralia - "KHABBI” atau "semua"- setelah "ORENG MADHURE”, untuk menunjukkan "orang Madura semua”. Relasi antar kata pada dasarnya mengandung pesan tersirat bahwa XL menjadi pilihan orang Madura sehingga diharapkan konsumen untuk memakainya. Artinya ajakan untuk memakai XL diatur secara tersirat dan tidak langsung.

\section{Bentuk Tata Bahasa dan Semantik}

Susunan kalimat dalam slogan memiliki struktur lengkap dengan subyek yang tersusun dari: kata benda (nomina); kata keterangan etnis atau tempat; dan kata keterangan numeralia, serta memiliki kata kerja, dan obyek. Pilihan kata langsung mengacu pada subyek dan obyek yang ditulis tersurat. Subyek adalah orang Madura semua ("ORENG MADHURE KHABBI”), sedangkan obyek adalah XL atau mengacu pada produk dan layanan merek XL. Sementara kata kerja "NGANGGUY” atau “memakai/menggunakan” hadir untuk memberi relasi aktivitas subyek terhadap obyek. Kata keterangan numeralia -“KHABBI” posisinya sebelum kata kerja dan setelah kata keterangan etnis atau tempat, sebenarnya membentuk kerancuan dalam kontruksi kalimat. Umumnya kata keterangan numeralia tersebut diletakkan sebelum kata benda yang ditunjukkan karakteristik numeralia-nya, bukan setelah kata keterangan lain, yaitu semestinya "KHABBI ORENG MADHURE” (artinya "semua orang Madura”) bukan “ORENG MADHURE KHABBI” (artinya “orang Madura semua”). Dilihat dari perspektif evaluasi terhadap struktur tata kalimat, bisa dipastikan, struktur kalimat ini terpengaruh bahasa tutur lisan yang tidak sistematis dan tidak memperhatikan struktur. Atau bisa dibilang, kalimat slogan tersebut hasil tutur lisan yang dituliskan.

Sementara jika dilihat dari perspektif komunikasi iklan, terutama penekanan kata dalam kalimat, keterangan dengan kata “ORENG MADHURE” dan “KHABBI” ini posisinya dalam kalimat memberikan informasi yang menentukan dan "menjual". Pengaturan posisi kata “ORENG MADHURE” di awal kalimat ingin menekankan siapa yang menggunakan XL. Maksudnya ingin menekankan dan menanamkan doktrin dalam pikiran (reminding) bahwa orang Maduralah yang menggunakan XL. Penekanan kata “ORENG MADHURE” dianggap lebih menjual karena secara langsung dan mula-mula menyebutkan dan menunjukkan identitas (etnis dan tempat) pemakai XL (orang Madura) di kalangan pasar lokal. Penyebutan dan peletakan dua kata di awal tersebut adalah materi utama persuasif untuk promosi produk XL dan menjadi latar depan dari promosi pendekatan lokal. 
Tetapi jika hanya menyampaikan pesan bahwa orang Madura menggunakan XL, kesannya tidak spesial dan biasa saja, hanya sekedar menunjukkan bahwa XL berhasil dipakai/digunakan orang Madura. Tidak ada bedanya jika produk provider lain juga digunakan masyarakat Madura. Sehingga pada teks slogan, untuk memberi nilai lebih promosi, subyek orang Madura tersebut dilengkapi dengan penekanan karakteristik, keunikan, identitas, sekaligus bentuk klaim "orang Madura semua menggunakan XL" dengan pemberian kata "KHABBI”. Sehingga "ORENG MADHURE KHABBI” dianggap kombinasi kata yang lebih menjual karena mengkonotasikan kuantitas atau pilihan favorit dengan konsumen terbanyak (semua orang Madura), bahwa XL merupakan satu-satunya pilihan operator telekomunikasi seluler yang dipakai orang Madura. Bahkan image yang dimunculkan selanjutnya adalah seolah-olah XL lebih menjadi kebanggaan lokal, dan menjadi dekat dengan perawat kebudayaan lokal, dan menjadi bagian dari kehidupan orang Madura.

Pengejawantahan pesan tersebut yang ditekankan dengan penggunaan kata “KHABBI” atau "semua” (dalam bahasa Indonesia) mau mengacu pada karakteristik majemuk/jamak keseluruhan atas jumlah konsumen atau besar jangkauan pasar di Madura yang menunjukkan "semua menggunakan XL". Kata "KHABBI” yang ditulis tersurat ingin menunjukkan secara langsung pengakuan dan klaim atas karakteristik besaran pasar yang dimiliki. Secara keseluruhan, organisasi antar kata menciptakan relasi hubungan pengetahuan, yaitu pihak yang tahu (pihak XL) ingin memberitahu pada pihak yang diberi tahu (masyarakat Madura) atas pernyataan dalam pesannya. Sebagaimana berdasar analisis fungsi iklan sebagai reminding pada uraian sebelumnya, XL sebagai pengiklan menunjukkan keinginan untuk mengingatkan masyarakat dengan cara menanamkan pemberitahuan bahwa "ORENG MADHURE KHABBI NGANGGUY XL". Kalimat dalam pesan teks slogan bersifat deklaratif atau membentuk ujaran pernyataan, bukan perintah atau ajakan tersurat. Pernyataannya yang menggunakan kata kerja saat sekarang, ditunjukkan dalam kata "NGANGGUY” atau "memakai/menggunakan", membuatnya tak terbatas waktu. Dengan kata lain, jika dibaca sekarang atau esok hari pun, tetap menunjukkan " tetap memakai XL”.

Uniknya, “ORENG MADHURE” yang merupakan target konsumen atau sasaran iklan disapa sebagai subyek (dalam kalimat) oleh pengiklan dengan kalimat aktif, sementara produk XL sendiri adalah obyek. Hal ini memberi arti bahwa seolah-olah orang Madura adalah subyek yang semata-mata menikmati produk XL. Padahal orang Madura adalah konsumen atau orang yang dibebani biaya konsumsi atau target yang dikuras uangnya, apalagi jika berlaku pada semua orang Madura sebagaimana pesan slogan. Orang Madura sejatinya obyek tetapi diatur sebagai subyek yang berkesan "diatur untuk menikmati”. Artinya target konsumsi sengaja dibiaskan untuk menutupi bahwa orang Madura adalah korban yang dijejalkan budaya konsumtif. Sehingga pengaturan kalimat aktif, serta organisasi subyek dan obyek yang demikian, seperti mau "menutup diri” bahwa XL semata-mata berusaha mementingkan keuntungan dari target konsumen orang Madura. Dan dianggap tidak cocok jika disampaikan dengan kalimat pasif, karena terlalu vulgar membuka maksud "hard selling” dari sistem kapital korporasi yang sematamata mementingkan keuntungan finansial dari konsumen masyarakat Madura. 
Peran aktor (pengiklan: korporasi) tidak terdapat pada teks. Bagian yang hilang dan sengaja diabsenkan itu dapat mengindikasikan maksud yang ditutupi. Temuan bagian yang hilang tersebut berimplikasi ditemukannya bagian yang hilang lain pada konfigurasi kalimat yang serupa pada bagian yang sejatinya maksudnya linear. Mula-mula, diubah realitas fungsi dan struktur kalimat bahwa sejatinya "semua orang Madura” adalah obyek pemasaran. Pada susunan kalimat pasif yang telah dibentuk dan disinkronisasi, yaitu “(produk) XL DIPAKAI SEMUA ORANG MADURA”, "semua orang Madura” menjadi obyek yang dibebani konsumsi produk XL. Kata dalam tanda kurung (dan huruf kecil) untuk menunjukkan kata yang dimaksud secara spesifik tidak dicantumkan. Sementara maksud yang mengkonotasikan upaya penetrasi produk XL yang nampak “dipaksakan” sebagai konsekuensi target pemasaran, dapat diketahui ketika kalimat dikonfigurasi ulang. Caranya dengan mencoba memasangkan bagian-bagian yang "samar" atau sengaja disembunyikan (dalam tanda kurung, huruf kecil), namun dalam kerangka maksud yang linear, menjadi "(produk) XL DIPAKAI(kan) (pada) SEMUA ORANG MADURA (oleh perusahaan $X L$ )”. Perhatikan ilustrasi teks di bawah ini (urutan nomor menyatakan langkah penyesuaian):

Asli (aktif): "ORENG MADHURE KHABBI NGANGGUY XL". Terjemahan (aktif): "ORANG MADURA SEMUA MEMAKAI XL"

Sinkronisasi terjemahan (aktif): "SEMUA ORANG MADURA PAKAI XL" Sinkronisasi terjemahan (pasif): "(produk) XL DIPAKAI SEMUA ORANG MADURA" Rekonfigurasi terjemahan (pasif): “(produk) XL DIPAKAI(kan) (pada) SEMUA ORANG MADURA (oleh perusahaan XL)”

\section{Perbendaharaan Kata}

Frasa “ORENG MADHURE” menunjukkan identitas orang atau masyarakat dengan karakter tertentu, yaitu mengacu pada identitas etnis Madura, Jawa Timur. Penyebutan frasa tersebut ingin menawarkan pendekatan pemasaran berbasis lokal dengan secara langsung menyebutkan entitas lokal yang dimaksud di wilayah lokal Madura sendiri. Pendekatan bahwa "yang global” (produk XL) dimiliki dan dipakai “yang lokal” (masyarakat Madura).

Selain itu, kata "KHABBI” menunjukkan nilai keunikan produk dari segi karakteristik jumlah pemakai. Kata tersebut menunjukkan besaran pasar, yang memberi keterangan dan karakteristik pada subyek yang disebutkan. Dalam hal ini mengacu pada "semua orang Madura”, meliputi “semua kelas sosial”, "semua usia”, "semua profesi”, dan lain-lain. Artinya, pemberian kata tersebut mau menunjukkan bahwa produk XL banyak dipakai oleh target pasar dan menjadi "pasaran”, sehingga tidak menargetkan eksklusivitas. Pemilihan kata ini mengkonotasikan produk pada nilainya yang menjadi favorit pilihan terbanyak yang dipakai oleh konsumen Madura.

Sebagaimana diketahui, kata "semua” menyatakan kondisi "seluruh" atau "total”. Antonim dari "semua” yaitu "beberapa” atau "sebagian”. Artinya kondisi "semua” atau "bukan beberapa" atau "bukan sebagian" tentu akan memunculkan antitesis pertanyaan kritis, “apakah benar semua?”, atau lebih lengkapnya, “apakah benar semua orang Madura memakai XL?”. Pertanyaan tersebut ingin mempertanyakan realitas atas 
pernyataan klaim “orang Madura semua memakai XL”. Apalagi jika pihak XL sendiri dalam laman resminya yang sudah diurai di atas, pada Desember 2015 tercatat memiliki jumlah pengguna terbanyak di Madura, yaitu sekitar 1,37 juta.

Pemilihan kata kerja transitif (yang membutuhkan obyek) "NGANGGUY” atau "memakai/menggunakan" dimaksudkan untuk menekankan pada perlakuan obyek, yaitu menjawab "memakai apa?”. Hal ini tentu saja menekankan pada pemakaian merek "XL" sebagai obyek yang disebut langsung, tanpa disebutkan sebagai "produk XL”, "layanan XL”, “operator XL”, dan lain-lain. Meskipun demikian, penyebutan secara majasi (metonimia) ini, secara tersirat sejatinya mengacu pada perihal produk dan layanan jasa XL. Termasuk dalam konsep branding, yaitu mengacu pada perihal fisik (produk kartu, dan lain-lain) dan nonfisik (janji, image, komunikasi, layanan, dan lain-lain) dari perusahaan XL.

Penulisan kata berbahasa Madura dalam iklan, terdapat kesalahan, sehingga berakibat pada kesalahan pelafalan. Penulisan slogan "ORENG MADHURE KHABBI NGANGGUY XL” seharusnya ditulis mengikuti ejaan penulisan bahasa Madura yang benar, agar pelafalan menjadi benar dan pesan dapat dipahami dengan benar pula. Dalam ejaan bahasa Madura yang benar, yaitu mengacu pada ejaan bahasa Madura terbaru (2004) (Muakmam, 2004), slogan tersebut harus ditulis "ORÈNG MADHURÂ KABBHI NGANGGHUY XL". Bahkan jika harus disinkronisasi dalam bahasa tulis yang tepat menjadi “KABBHI ORÈNG MADHURÂ NGANGGHUY XL”. Jika hanya memandang dari segi komunikasi (tujuan utama pesan tersampaikan) dan kemudahan penulisan teks, slogan juga dapat ditulis tanpa tanda diakritik (di atas huruf) sesuai ejaan bahasa Madura 1973, yaitu "ORENG MADHURA KABBHI NGANGGHUY XL".

Karakter È atau è pada kata "ORENG" disebut vokal "È taleng", sedangkan karakter Â atau â pada kata "MADHURÂ" disebut vokal "Â capeng”. Vokal "È taleng” dengan tanda baca di atas huruf "E" sama pelafalan dan bunyinya dengan vokal "e" pada kata (dalam bahasa Indonesia): "seksi”; “peci”; atau "teks”, untuk membedakan dengan vokal "E petpet” seperti dalam pelafalan dan bunyi vokal "e” pada kata (dalam bahasa Indonesia): "kecil”; “keris"; atau "besar”. Begitu pula huruf “Â capeng” sama pelafalan dan bunyinya dengan vokal "e” pada kata (dalam bahasa Indonesia): "besar”, “deru”, dan lain-lain.

Pemberian tanda tersebut serupa dalam set characters (kelengkapan karakter) alfabet Latin, dengan penambahan tanda baca pada karakter bahasa asing (seperti Jerman atau Perancis) untuk melengkapi set characters yang disebut foreign accents (Sihombing, 2001: 34). Dalam foreign accents, karakter dengan tanda baca seperti À, à, È, è, İ, ì, Ò, ò, Ù, ù, disebut "grave", sedangkan karakter dengan tanda baca seperti Â, â, Ê, ê, Î, î, Û, û, Ô, ô, disebut “circumflex”. Penamaan istilah karakter dengan tanda baca tersebut misalnya dapat dilihat di fitur symbol pada piranti lunak berbasis office seperti Microsoft Word.

Selain itu, Kata "KHA” seharusnya ditulis “ $K A$ ”, karena konsonan "K” tidak dilafalkan dengan berat, justru konsonan " $K$ " dilafalkan tajam, sehingga tidak harus mendapat/diikuti karakter haspira "H". Dan konsonan "BI" pada "KHABBI" semestinya dilafalkan halus berat sehingga harus ditulis "KABBHI". Begitu pula konsonan " $G$ ” pada 
kata "NGANGGUY" harus dilafalkan halus berat, sehingga harus ditulis "NGANGGHUY".

Kata-kata dalam slogan menggunakan tingkatan bahasa bawah (enjâ'-iyâ), yang hanya bisa ditunjukkan dengan dua kata "KHABBI" dan "NGANGGUY". Tingkat bahasa enjâ'-iyâ biasa dipakai sebagai bahasa sehari-hari yang digunakan oleh orang yang lebih tua pada orang yang lebih muda, atau sesama anak-anak (Bastari dan Fiandarti, 2009: 42). Sejalan dengan misi pesan yang mengklaim bahwa XL dipakai semua (kalangan) orang Madura, penggunaan tingkatan bahasa ini dalam mengkonstruksi teks maunya untuk menyesuaikan dengan bahasa pasaran secara luas. Karena tingkatan bahasa ini paling mudah dan umum dipraktikkan khalayak, serta dimengerti anak-anak hingga dewasa. berbeda dengan bahasa tingkat madya (êngghi-enten) dan tingkat atas/halus (êngghibunten) yang cenderung sulit dimengerti karena belum tentu biasa dipraktikkan dalam kehidupan sehari-hari.

\section{Evaluasi}

Evaluasi terhadap iklan ini dapat memberi gagasan kritis. Berdasarkan unsur visual dan verbal (teks) iklan, baik dari sisi estetik dan semantik, ditemukan bahwa iklan XL diupayakan untuk penetrasi semua kalangan Madura. Sayangnya, dalam teks iklan yang mengandung pesan utama iklan, penggunaan kata "KHABBI" yang mengacu pada semua orang Madura, kesannya meragukan dan justru membohongi publik. Sebab tidak ada bukti atau data yang dicantumkan. Begitu pula realitasnya, salah satu atau dua orang orang Madura yang penulis jumpai tidak menggunakan XL, yang artinya sebagian orang Madura tidak menggunakan XL. Premis “sebagian” tentu bertentangan dengan “semua”. Selain itu, berdasarkan sajian data jumlah konsumen dari pihak XL sendiri, realitanya tidak semua orang Madura yang menjadi konsumen XL, yaitu pada 2015 mencapai sekitar 37, 8\% dari jumlah penduduk Madura, berdasarkan Sensus Penduduk 2010 (SP 2010).

Jika maksudnya mengacu pada nilai produk yang paling banyak digunakan masyarakat Madura, pemilihan kata "semua” cenderung ekstrim dan menunjukkan klaim berlebihan. Bisa dibilang melalui pernyataan dalam slogan tersebut, dunia konsumen dan kebutuhan akan produk XL merupakan histeria yang digeneralisir dan dihiperbolakan. Justru hal tersebut merupakan "manipulasi tanda" yang memaksakan konsensus, bahwa XL dipakai semua orang Madura. Seperti yang Baudrillard (1983: 116-117) sampaikan bahwa pesan iklan merupakan kode yang harapannya diikuti secara sendirinya oleh konsumen karena adanya konsensus (referendum) yang dipaksakan tanpa referensi lain. Pola penekanan kata “KHABBP” yang nyata-nyata ditulis secara literal atau tersurat, bukan tersirat, ingin menunjukkan linearitas representatif dari pola pikir stereotipikal masyarakat Madura yang pemahamannya secara literal dianggap sederhana, lugas, dan tidak berbelit-belit. Organisasi teks slogan yang sederhana, lugas, dan tidak berbelit-belit, mudah dipahami maknanya, dan gamblang secara literal sebagai sarana beriklan dianggap laku dan mudah dimengerti masyarakat Madura.

Pola komunikasi melalui teks slogan yang demikian, secara literal atau tersurat pula, justru ingin menunjukkan dukungan terhadap ketidakberesan sosial yang 
mengesankan masyarakat Madura mudah dibodohi dan dibohongi oleh korporasi sebagai pengiklan. Karena pernyataan dalam slogan yang menyatakan klaim kuantitas secara literal, nyatanya mudah ditanggapi dengan penalaran logika kritis untuk diragukan dan dipertanyakan ujaran klaimnya. Selain itu, alasan lainnya adalah nyatanya XL tidak menawarkan atau melakukan monopoli pasar yang merupakan satu-satunya operator telekomunikasi yang dipakai konsumen masyarakat Madura. Baik dari bukti statistik di atas maupun bukti keseharian (dari beragam konsumen layanan telekomunikasi selular sekitar penulis), dapat diketahui beragam pilihan alternatif provider layanan telekomunikasi yang dipakai masyarakat.

Dengan kata lain, korporasi XL tidak pernah peduli dengan edukasi dan perbaikan tingkat intelektualitas masyarakat Madura dalam pola pemahaman iklan dan konsumsi, meskipun simbol identitas kebudayaan lokal menjadi senjatanya dalam strategi pemasaran. Pertanggung-jawaban sosial korporasi (corporate social responsibility) hanya parsial pada pelayanan komunikasi yang menguntungkan secara finansial. Sehingga penting bagi korporasi untuk mengevaluasi strategi beriklannya di Madura, dengan memunculkan strategi iklan yang mencerdaskan dan saling menguntungkan, bukan hanya untung sepihak, mengingat XL adalah perusahaan tamu yang "kulonuwun” dengan izin pemasaran di arena lokal Madura.

Namun, karena korporasi memiliki target benefit, akhirnya penetrasi materi iklan -“ORÈNG MADHURÂ KABBHI NGANGGHUY XL”- untuk menumbuhkan hasrat konsumtif, dimanipulasi lebih ditekankan secara tersurat bukan pada fungsi kenikmatan, tapi pada fungsi kolektif identitas sosial budaya. Yaitu membangun motivasi konsumsi melalui alasan kolektivitas (semua) warga (identitas) Madura menggunakan XL. Sebagaimana dikatakan Baudrillard (1983: 129), propaganda kebutuhan akan produk dimunculkan karena fungsi sosial atau fungsi kolektif, bukan fungsi kenikmatan. Fungsi iklannya yang dipakai sebagai reminding, memunculkan kesan persuasif akan harapan pengiklan agar konsumen masyarakat Madura memakai dan tetap memakai XL. Pesan slogan merupakan kode yang harapannya diikuti secara sendirinya oleh konsumen, sebagaimana menurut Baudrillard di atas. Jika masyarakat banyak menggunakan XL, maunya justru calon konsumen baru akan juga mulai menggunakan XL dan konsumen lama akan tetap loyal menggunakan XL, karena pertimbangan masyarakat sudah banyak menggunakan XL (karena secara kolektif masyarakat Madura menggunakan XL). Selain itu, motivasi kebutuhan kolektif, juga didasari pergeseran ketertarikan karena sama-sama satu identitas simbolik, yaitu masyarakat etnis Madura.

Kesamaan identitas sosial budaya konsumen akan cenderung lebih mengedepankan ikatan sosial yang relatif lebih kuat, misalnya memunculkan rasa kesamaan, kebanggaan, kesatuan, kekeluargaan, dan keakraban, yang mempengaruhi corak pasar. Dengan kata lain, dalam hal ini, pola komunikasi iklan XL di atas juga berkaitan dengan pola relasional masyarakat yang berkomunikasi dengan masyarakat lokalnya, sehingga mempengaruhi pertimbangan masyarakat dalam memilih operator layanan telekomunikasi selular.

Sebagai ilustrasi, sebagai konsumen, orang Madura akan relatif lebih cenderung memilih menggunakan XL jika lawan bicaranya (via telekomunikasi selular) juga menggunakan XL, apalagi jika seolah-olah diungkapkan bahwa secara kolektif 
masyarakat Madura lebih banyak menggunakan XL. Sebab kecenderungan pertimbangannya adalah dampaknya pada beban biaya konsumsi (layanan suara/telepon dan layanan pesanan singkat) yang digadang-gadang cenderung relatif murah jika antar sesama operator. Begitu pula dari sisi potensi pasar luar daerah Madura, sebagaimana diketahui bahwa Madura adalah daerah lokal yang menjadi tujuan mudik bagi warga Madura yang merantau, sehingga XL tetap dapat menjadi pilihan masyarakat Madura untuk menyambung komunikasi dengan keluarga di daerah perantauan. Dalam hal ini, misalnya barangkali layanan suara sesama XL akan menjadi alternatif pilihan sehingga memungkinkan konsumen tersebut berlama-lama berbicara untuk melepas rindu atau membicarakan hal lain.

Mengingat hubungan konsumsi layanan telekomunikasi seluler membutuhkan relasi dari orang lain yang demikian, kecuali layanan data internet. Maka dari iklan, diharapkan muncul dan bertahan kelompok "masyarakat XL", yaitu masyarakat yang secara kolektif sama-sama menggunakan XL. Dengan demikian, jaringan pola konsumsi yang dibentuk berupa sistem sirkulasi tertutup, dimana XL menjadi menarik karena dibutuhkan dan dipakai orang lain (secara kolektif oleh orang Madura).

Pernyataan dalam slogan seolah menjadi cermin yang seolah-olah mereduplikasi keinginan, sehingga calon konsumen berikutnya terpengaruh dan mau tidak mau akan mengikuti pola sistem konsumsi tersebut. Dalam hal ini, "masyarakat akan mengikuti ritme produk kebutuhan dan pergantiannya terus menerus” (Haryatmoko, 2016: 64). Munculnya kebutuhan bukan hanya karena keinginan konsumen yang otonom (misalnya untuk kebutuhan komunikasi jarak jauh saja), tetapi bisa diciptakan dan didikte dari iklan karena hasrat untuk konsumsi diinginkan orang banyak. Sehingga muncul motivasi pada konsumen untuk menyesuaikan dengan orang banyak dengan menggunakan XL, agar beban tarif pemakaian dalam berkomunikasi menjadi lebih murah, misalnya. Pernyataan dalam slogan juga dapat dianggap sebagai strategi kekuasaan, yaitu untuk menumbuhkan kesan dominasi ekonomi. Artinya pernyataan tersebut manifestasi upaya mengejar dan mempertahankan kekuasaan pasar, dalam hal ini kekuasaan dalam persaingan ekonomi kapitalis. Sebagai akibatnya target yang didominasi yaitu konsumen Madura harus mengikuti pola-pola aturan penguasa kapital korporasi XL.

Strategi kekuasaan ini dapat dilihat dari perspektif Bourdeau. Strategi ini merupakan bagian usaha untuk mempertahankan kepemilikan kapital ekonomi, yaitu jaringan pasar XL di Madura sebagai sumberdaya yang menjadi sarana finansial. Dalam konteks pendekatan promosi Madura yang dilakukan pengiklan, sejatinya strategi tersebut merupakan usaha konversi kapital ekonomi dari kapital sosial dan budaya (Bourdieu, 1998: 19-20). Kapital sosial merupakan jaringan hubungan sumber daya sosial, dalam hal ini jaringan pasar di Madura (Bourdieu, 1998: 16, 70-71, 107, dan Haryatmoko, 2016: 45). Sedangkan menurut Bourdieu (1998: 5-7, 15-16) dan Haryatmoko (2016: 45) kapital budaya merujuk pada kode atau identitas budaya, etnis, cara bertutur/berkomunikasi/ berbahasa, cara bergaul/pendekatan yang dalam hal ini adalah masyarakat lokal Madura, dengan pendekatan iklan berbahasa Madura yang menjadi sumber daya (kapital) untuk instrumen pemasaran XL.

Oleh karena itu, sebagaimana analisis teks pada bagian sebelumnya, untuk melancarkan strateginya ini, aktor (pengiklan) tidak dicantumkan atau “dihilangkan”, dan 
masyarakat Madura sebagai target konsumsi dibiaskan seolah-olah menjadi subyek yang semata-mata menikmati produk. Kapitalisasi korporasi semata-mata mementingkan keuntungan finansial dari konsumen masyarakat Madura. Apalagi jika penekanannya adalah "semua orang Madura” diajak secara tersirat untuk menggunakan XL, maka jangkauan pasar semakin luas, sumber daya kapital di Madura semakin besar. Namun, masyarakat yang hanya menjadi obyek "penderita” yang dibebani biaya konsumsi, tetap merasa biasa saja, tidak terjadi apa-apa, karena merasa kebutuhan telekomunikasinya dibantu XL.

Di samping itu, dari segi penulisan teks iklan berbahasa Madura yang memiliki banyak kesalahan, dalam proses penciptaan kreatifnya terkesan sembarang, ngawur, serba asal tulis, asal tahu, asal bisa dituturkan, tanpa mempertimbangkan kaidah-kaidah yang ada maupun dari pendapat pihak ahli atau yang paham mengenai bahasa Madura. Sama halnya dengan kata-kata dalam bahasa Inggris yang bila ditulis sembarang, hilang atau terbalik satu atau susunan huruf, maka kata sulit terbaca dan pesan tak tersampaikan maksudnya. Hal ini mengindikasikan tidak adanya upaya riset maupun komunikasi dan konsultasi intens dengan pihak-pihak setempat yang paham. Sehingga memunculkan ekses negatif image XL yang kurang profesional dalam menyasar segmentasi kebudayaan pasar lokal setempat.

Namun dalam konteks iklan XL ini, meskipun tulisan dapat terbaca, dan dapat ditangkap maksud pesannya, penulisan yang fatal salah mengkonotasikan bahwa korporasi yang bersangkutan tak pernah ambil peduli pada edukasi dan perawatan tradisi kebudayaan lokal, khususnya dalam konteks kebahasaan. Padahal, kebudayaan lokal, dalam hal ini bahasa lokal, justru menjadi instrumen utama dalam pendekatan untuk menyasar pasar lokal dan mendatangkan keuntungan yang potensial. Lagi-lagi, modus kapitalis untuk mendatangkan keuntungan dari masyarakat lokal diduga lebih menjadi perhatian, daripada upaya membantu merawat kebudayaan (bahasa daerah) yang non profit.

Jelas bentuk kapitalisme konsumen yang menjadi bentuk obsesi pengiklan adalah “dominasi kapital” bahwa XL menjadi “favorit bagi orang Madura” yang dijejalkan pengiklan. Yaitu melalui pendekatan identitas lokal (sosial dan budaya) dan karakteristik besar jaringan pasar. Karena iklan erat dengan simbol-simbol kebudayaan dan ideologi. Sebagaimana menurut MacRury (2009) iklan adalah seni resmi dari masyarakat kapitalis. Bisa dibilang iklan adalah perpanjangan tangan untuk menyampaikan pesan-pesan untuk menopang kapitalisme dan masyarakatnya, dalam hal ini dengan pendekatan simbol dan identitas lokal di kawasan lokal Madura.

\section{Kesimpulan}

Ragam promosi Xl dengan iklan berstrategi pendekatan kebudayaan lokal Madura merupakan upaya menyasar pasar lokal. Iklan yang demikian, misalnya yang dijumpai penulis berupa medium iklan luar ruang dan label kursi konsumen kedai seluler, diduga memiliki fungsi pengingat (reminding) terhadap merek XL. Hal ini diidentifikasi dari komposisi iklannya yang menonjolkan unsur visual yang relatif besar dan kontras, 
dengan ilustrasi utama logo XL, tanpa ilustrasi lain yang dibuat khusus, serta teks slogan singkat, memungkinkan dapat terbaca cepat dan relatif mudah diingat.

Baik dari segi estetik visual dan semantik, dapat ditangkap pesan yaitu ingin mengkomunikasikan bahwa XL adalah operator favorit pilihan masyarakat Madura. Penekanan ini rupanya ditulis tersurat dengan pernyataan bahwa orang Madura semua menggunakan XL. Sayangnya, pernyataan "semua” tidak mengacu pada kondisi realitas, tetapi bentuk manipulasi ekstrim untuk menyatakan dominasi dan mempertahankan kekuasaan dalam lingkup pasar Madura.

Justru pola konsumsi dengan organisasi kapital mendikte konsumen dengan iming-iming fungsi kolektif melalui materi "identitas dan simbolik” kebudayaan Madura. Bahwa XL menjadi menarik karena digunakan orang lain secara kolektif, sehingga harus ikut menggunakan agar mendapat manfaatnya, bukan karena keinginan konsumen yang otonom, misalnya kebutuhan agar tarif lebih murah jika terhubung ke sesama operator. Selain itu, iklan juga seolah-olah berusaha menyamarkan fakta bahwa masyarakat Madura adalah target konsumsi, untuk mendatangkan keuntungan kapitalistik.

Hal ini sekaligus memunculkan kritik bahwa pesan teks yang menyatakan segenap masyarakat ditekankan dekan premis slogan -“KHABBI” atau "semua” secara tersurat, jelas-jelas ingin menunjukkan dukungan terhadap ketidakberesan sosial yang mengesankan masyarakat Madura mudah dibodohi dan ditipu oleh korporasi. Dengan kata lain, korporasi XL tidak pernah peduli dengan edukasi dan perbaikan tingkat intelektualitas masyarakat Madura dalam pola beriklan dan konsumsi, meskipun simbol identitas kebudayaan lokal menjadi senjatanya dalam strategi pemasaran. Selain itu, penulisan ejaan teks iklan yang fatal salah, terkesan sembarang, ngawur, dan serba asal tulis, mengkonotasikan bahwa korporasi yang bersangkutan tak pernah ambil peduli pada edukasi dan perawatan tradisi kebudayaan lokal, khususnya dalam konteks kebahasaan.

\section{Kepustakaan}

Bastari dan Fiandarti, Yoesi Ika. 2009. Kosa Kata Bahasa Madura Lengkap. Surabaya: Karya Simpati Mandiri.

Baudrillard, Jean. 1983. Simulations. (English Translation). USA: Semiotext(e).

Bourdieu, Pierre. 1998. Practical Reason - On The Theory Of Action. California: Standford University Press.

Fashri, Fauzi. 2014. Pierre Bourdieu: Menyingkap Kuasa Simbol. Yogyakarta: Jalasutra. Haryatmoko. 2016. Membongkar Rezim Kepastian - Pemikiran Kritis Post-Strukturalis. Yogyakarta: Kanisius.

MacRury, Iain. 2009. Advertising. London dan New York: Routledge.

Muakmam. 2004. Ėjhâân Bhâsa Madhurâ 2004. Surabaya: Karunia offset printing.

Ricoeur, Paul. 2012. Teori Interpretasi. Yogyakarta: IRCiSoD.

Sihombing, Danton. 2001. Tipografi dalam Desain Grafis. Jakarta: Gramedia.

XL Axiata. Sejarah. [Online] Tersedia: http://www.xl.co.id/corporate/id/perusahaan/profil/sejarah. Diakses pada 9 Juni 2016, pukul 10.39 WIB 
Blambot.com. Badaboom BB. [Online] Tersedia: http://www.blambot.com/font_badaboom.shtml. Diakses pada 11 Juni 2016, pukul 10.56 WIB.

XL Axiata. (28 Desember 2015). Kerjasama XL - Pemkab Pamekasan Tingkatkan Produktivitas Nelayan Nelayan Madura Mulai Manfaatkan mFish. [Online] Tersedia: http://www.xl.co.id/corporate/id/ruang-media/nasional/kerjasama-xlpemkab-pamakasan-mfish. Diakses pada 9 Juni 2016, pukul 10.38 WIB.

Sindonews.com. (6 Mei 2015). Telkomsel siapkan jaringan di Madura. [Online] Tersedia: http://daerah.sindonews.com/read/997948/151/telkomsel-siapkan-jaringandi-madura-1430885656. Diakses pada 11 Juni 2016, pukul 10.51 WIB.

XL Axiata. (28 Oktober 2014). Pertama di Indonesia XL Luncurkan Layanan Real Mobile 4G-LTE. [Online] Tersedia: http://www.xl.co.id/corporate/id/ruangmedia/nasional/xl-luncurkan-layanan-real-mobile-4g-lte. Diakses pada 9 Juni 2016, pukul 10.37 WIB.

Kabarbisnis.com. (14 Mei 2009). [Online] Tersedia: http://www.kabarbisnis.com/read/282600/xl-pasang-79-mbc-di-madura. Diakses pada 9 Juni 2016, pukul 11.05 WIB.

Kabarbisnis.com. (6 Juni 2014). Perkuat pasar Madura, XL gelontor ratusan BTS baru. [Online] Tersedia: http://www.kabarbisnis.com/read/2847908/perkuat-pasar-madura-xl-gelontor-ratusan-bts-baru. Diakses pada 9 Juni 2016, pukul 12.50 WIB.

Badan Pusat Statistik (BPS). Sensus Penduduk 2010. [Online] Tersedia: http://sp2010.bps.go.id/index.php/site?id=35\&wilayah=Jawa-Timur. Diakses pada 9 Juni 2016, pukul 13.41 WIB.

JPNN. (25 Juni 2013). Indosat Agresif Bidik Pasar Madura. [Online] Tersedia: http://www.jpnn.com/read/2013/06/25/178511/Indosat-Agresif-Bidik-Pasar-Madura 